\title{
ДВУМЕРНОЕ ДИНАМИЧЕСКОЕ МОДЕЛИРОВАНИЕ СЕЙСМИЧЕСКОЙ ЗАПИСИ С ЦЕЛЬЮ ОЦЕНКИ СТРОЕНИЯ И ФЛЮИДОНАСЫЩЕННОСТИ ПЕРСПЕКТИВНЫХ ОБЪЕКТОВ.
}

Ганиев В.А., Макозюб́ Н.В., Боброва П.В.

(ООО «Славиефть-НПЦ г. Тверь)

Конечной целью геологической интерпретации сейсмических материалов является создание сейсмогеологической модели (решение обратной задачк), которая содержит конкретный набор сведений, характеризующих как морфологические, так и фациальные особенности изучаемого геологического разреза. В настоящее время созданную таким образом сейсмогеологическую модель принято оценивать как продукт последнего этапа ивтерпретация, и если такая модель не противоречит имеющимся данным бурения, пересмотр её и коррекция выглядят неуместными. На самом деле существуют определённые возможности, связанные с двумерным динамическим моделированием, которые позволякот рассматриваемую сейсмогеологическую модель путём решения прямой задачн пересчитать в синтетику и оценить на предмет корректности её создания на основе сравнения волновых картин синтетики и реального разреза.

Именно применение двумерного динамического моделирования для целей оценки корректности созданной сейсмогеологической модели можно рассматривать как заключительный этап интерпретация, на котором принимается решение: рекомендовать использование модели для дальнейших геологических изысканий и возможного мониторинга или в определённом направлении её доработать.

Предположение о возможном наличии нефтяной залежи в своде северной структуры по пластам БС $10,5 C_{8}$ и БС 6 возникло на основе некоторых особенностей волновой картины, соответствующей рассматриваемому интервалу геологического разреза. Тому причиной явилась заметная интерференция регистрируемых осей синфазности и специфический дисбаланс в динамике отражений. С целью оценки степени достоверности выдвинутого предположения было выполнено двумерное динамическое моделирование во временной области. В качестве геометрии модели была выбрана геометрия осей синфазности реального сейсмического разреза. Для расчёта и присвоения элементам модели скоростных параметров и временныг толщин использоваљись данные ГИС. В связи с отсутствием сведений о плотностных параметрах геосреды непосредственно на площади работ и учитывая имеющиеся сведения о низкой её дифференциации в региональном плане, для расчёта двумерной модели использовалось постоянное значение плотности равное $2,56 \mathrm{r} / \mathrm{cm}^{3}$. Импульс для свёртки извлечён из реального волнового поля. На основе вышеперечисленных данных и применения программы SM_2D (разработка OOO «Славнефть-НПЦ») была полудена исходная двумерная синтетическая модель. Далее, на основе сравнительного анализа синтетики реального разреза возникла необходимость в её коррекции. Данная операция осуществлялась с использованием программы SINTADJ (разработка OOO «Славнефть - НПЦџ), которая осуществляла латерально гладкую коррекцию значений акустических жесткостей модели, не изменяя геометрию отражающих границ. Такое ремение обратной задачи позволило добиться адекватности модели реальным сейсмическим данным. Мерой адекватности явился вычисленный в программе (по трассам) коэффициент корреляции синтетических и реальных трасс, который равнялся 0,975 . Полученный результат является предварительным этапом расчёта, и он не даёт ответа на вопрос о том, каким образом меняется волновое поле, если в своде структуры мы имеем углеводородное насыщение коллектора, однако, с помощью этой операщи нам удалось уточнить модель.

Цель следующего этапа - создание синтетической модели без влияния возможного углеводородного насышения продуктивных пластов. Из разреза импедансов уточнённой модели, извлекались две трассы в точках, симметрично расположенных по обеим сторонам антиклинального перегиба. Эти точки рассматривались, "как некие виртуальные скважины, в которых рассчитанным импедансам присваивался статус опорных данньх для расчёта следующей динамической модели. В этом случае необходимо понимать, что одним из основньгх условий корректного решения поставленной целя является достаточная степень уверенности в том, что выбранные точки расчёта опорных импедансов располагались вне зоны предполагаемого углеводородного насыщения продуктивных пластов. Таким образом в рамках геометрии отражающих границ рассчитывается двумерная динамическая модель, которая соответствует разрезу без возможного нефтенасышения продуктивных пластов.

Следующий этап двумерного динамического моделирования заключался в расчёте модели с вложением нефтяных залежей. В этом случае пересчёт коэффициентов отражения в зонах развития нефтяных залежей осуществлялся с использованием следующих параметров: плотность нефти принималась равной $0.795 \mathrm{r} / \mathrm{cm}^{3}$, плотность пластовой воды - 1.01 $\Gamma / \mathrm{cm}^{3}$ и козффициент пористости продуктивных отложений $-15 \%$. Плотность нефти и воды в пласте была взята из результатов испытаний пласта $\mathrm{БC}_{10}$ близлежащего месторождения. Оценивая полученные результаты можно отметить, что предположение о наличии нефтенасыщенных интервалов разреза, куда входят продуктивные пласты $\mathrm{БC}_{10}, \mathrm{БC}_{8}$ и БС $_{6}$ в своде выявленного поднятия имеет достаточно весомое основание, о чём свидетельствует заметная, как кинематическая, так и динамическая схожесть волновых картин синтетической модели с вложением нефтяных залежей и реального временного разреза. Коэффипиент корреляции синтетического разреза без вложения нефтяной залежи с реальным разрезом $-0,758$, а с вложением нефтяной залежи 0,810 .

Все графические результаты работ будут представлены непосредственно в докладе. 